\title{
Supporting the patients with advanced cancer and their family caregivers: what are their palliative care needs?
}

Gek Phin Chua ${ }^{* *}$ D, Grace Su Yin Pang ${ }^{2}$, Alethlea Chung Pheng Yee ${ }^{3}$, Patricia Soek Hui $\mathrm{Neo}^{3}$, Siqin Zhou 4 , Cindy Lim ${ }^{4}$, Yin Yee Wong ${ }^{5}$, Debra Limin Qu ${ }^{3}$, Fang Ting Pan ${ }^{6}$ and Grace Meijuan Yang ${ }^{3}$

\begin{abstract}
Background: The impact and consequences of cancer on the patients and their family caregivers (FCs) are closely intertwined. Caregivers' burdens can be increased due to the patients' unmet needs and unresolved problems. Additionally, the caregivers' unmet needs may adversely affect their own well-being and the patients' health outcomes. This study aims to determine the palliative care needs and the factors associated with these needs in patients with advanced solid cancer and their FCs.
\end{abstract}

Methods: In a cross-sectional survey, 599 patients with advanced solid tumours and 599 FCs were recruited from the largest ambulatory cancer centre and the inpatient ward of the largest hospital in Singapore. Determinants of patients' and FCs' needs were assessed by the Comprehensive Needs Assessment Tool (CNAT) and CNAT-C respectively. Clinical characteristics of patients were obtained from medical records.

Results: The FCs (median age 51 years) were younger than the patients (median age 62 years), and were mostly female (62.6\%) whereas the gender distribution of patients was quite balanced (49.2\% male and $50.8 \%$ female). Both patients and FCs had "information" and "practical support" in their top three domains of palliative care needs. The second highest domain of needs was "psychological problems" $(16.4 \pm 21.5)$ in patients and "health-care staff" (23.4 \pm 26.5$)$ in FCs. The item that had the highest need score in "information" domain for both patients and FCs was "financial support for patients, either from government and/ or private organizations". Under clinical setting, the inpatients $(19.2 \pm 16.4)$ and their FCs $(26.0 \pm 19.0)$ tend to have higher needs than the outpatients $(10.5 \pm 12.1)$ and their FCs $(14.7 \pm 14.3)$. In terms of palliative care, higher total CNAT score was observed in both patients (16.6 \pm 12.9 versus $13.3 \pm 15.2)$ and their FCs (25.1 \pm 18.6 versus $17.7 \pm 16.7)$ who received palliative care. In terms of patients' KPS scores, patients with lower KPS scores tend to have higher needs.

Conclusion: Overall, the findings confirm that patients with advanced cancer and their FCs have many palliative care needs irrespective of their clinical settings. Initiatives and interventions for the development of a comprehensive support system for both patients with advanced cancer and their FCs are warranted and can be derived from these findings.

Keywords: Advanced cancer, Cancer patients, Caregivers, Palliative care, Needs, Oncology

\footnotetext{
* Correspondence: chuagekphin2@gmail.com

${ }^{1}$ CEIS (Research \& Data), National Cancer Centre Singapore, 11 Hospital Crescent, Singapore, Singapore 169610, Singapore

Full list of author information is available at the end of the article
} 


\section{Background}

Medical advances in the treatment of cancer have enabled patients diagnosed with advanced cancer to live for a relatively long period. This change in prognosis may bring considerable needs and problems to both patients and caregivers. Physical dysfunction [1] cognitive dysfunction $[2,3]$, psychological dysfunction [2] and economic, financial and insurance concerns $[2,4,5]$ have been identified as long-term consequences of cancer and its treatment.

Family caregivers (FCs) play an integral role in the care and support of cancer patients. They may assume diverse responsibilities during the patient's disease trajectory providing physical, emotional, social, spiritual and financial support $[6,7]$. The long-term process of providing care is physically and psychologically demanding, especially when caring for patients with advanced cancer. The burden of caregiving may manifest in symptoms of sleep difficulties, depression, anxiety, tension, panic, or behaviours that may jeopardize the FC's health [5, 6, 8-14]. FCs of patients with terminal cancer can experience an even higher burden as the patient's condition deteriorates and family financial resources become exhausted and physical energy and emotions are drained [15].

The impact and consequences of cancer on the patients and their FCs are closely intertwined. Evidence in literature indicates that the level of caregiver burden can be increased due to the patient's unmet needs [16]. In addition, the challenges that caregivers experienced are closely related to the well-being of the patients [14]. Unresolved problems or unmet needs of caregivers will not only adversely affect the caregivers' own well-being [11] and decrease their quality of life $[17,18]$ but also the patients' health outcomes [19]. Conversely, the health status of patients may improve due to expertise, confidence, and ability of the caregivers to provide quality care [7].

Despite being a relatively young nation, Singapore has attained a relatively high standard of health. Life expectancy for males is 81 years and females is 85.4 years [20]. Like many developed countries, cancer has been the leading cause of mortality in Singapore. Unlike many developed nations such as the United Kingdom and Australia, the development of palliative care was slow due to the Asian taboos regarding dialogue about death and dying [21]. Palliative care as defined by World Health Organization is "an approach that improves the quality of life of patients and their families facing the problem associated with life threatening illness, through the prevention of suffering by means of early identification and impeccable assessment of pain and other problems, physical, psychosocial and spiritual" [22]. The aim of palliative care is to improve the quality of life (QOL) for individuals with a life-limiting illness and their families [23].
Efforts have been made to expand and improve palliative care in Singapore such as raising public awareness, redesigning healthcare professionals' education and improving funding by the state. It was only in 2006 that palliative medicine was recognized as a medical specialty in Singapore [21] and is increasingly becoming a part of mainstream medicine and acknowledged as an essential part of the healthcare system. The first hospice with 16 beds was set up by a group of Catholic nuns at the St. Joseph Home in 1985 [21] for dying patients. Over the years, the scope and range of palliative care services have expanded. Palliative care is now being offered in hospitals, hospices and home and is extended to non-cancer patients. There are also plans to introduce palliative care early in the course of a potentially life-limiting illness [24].

In order to provide high quality patient and family centered care, the care needs of both patients and FCs should be comprehensively assessed. Assessing the needs of both patients and their FCs is critical to guide care planning in supporting them to cope. Relatively, few studies have explored the needs of caregivers of cancer patients [12, 13, 15, 18, 25-28] and even fewer studies have investigated these needs directly from the patients and their FCs [15]. Moreover, the needs of patients and their FCs in Singapore may differ from that in other countries because of differing cultural norms and expectations. Only a few studies have evaluated the experience of Singapore caregivers of cancer patients and they are related to burden of care [29], quality of life [30] and unmet needs [17].

The purpose of this study is to determine the palliative care needs and the factors associated with these needs in patients with advanced solid cancer and their FCs; and identify gaps in palliative care services that need to be addressed. To the best of our knowledge, this is the first assessment and analysis of the palliative care needs of both patients with advanced cancer and their FCs in Singapore. The body of knowledge derived from this study would provide an evidence-based approach in the delivery of patient and family centric palliative care. It would further add to the growing literature on the palliative care needs of patients with advanced cancer and their FCs.

\section{Methods}

Participants, settings and study procedure

An exploratory cross-sectional survey was conducted at the outpatient clinics of the National Cancer Centre Singapore (NCCS, the largest public ambulatory cancer centre in Singapore), and at the inpatient wards of the Singapore General Hospital (the largest hospital in Singapore and the admitting hospital for patients from the NCCS). Eligible patients were first identified by the primary physician or palliative care team the patient was 
referred to. The trained research coordinator would help the physicians and team to identify eligible patients by pre-screening through the outpatients or inpatient resource list or the referring team contacts the research coordinator when there is an eligible caregiver. The inclusion criteria for patients were: (1) aged 21 years and above (the age of majority), (2) able to understand English or Mandarin, (3) intact cognition, (4) diagnosed with advanced solid tumour that is not under curative treatment, (5) Karnofsky performance status $\geq 20$ and, (6) agreed to participate in this study. Inclusion criteria for caregivers were: (1) aged 21 years and above, (2) able to understand English or Mandarin, (4) family members of patients with advanced solid tumour that is not under curative treatment and, (5) agreed to participate in the study. The patients were asked to identify their primary FC, defined as a relative who provided them with the most assistance in terms of physical caregiving or decision making.

Eligible patients and FCs were assessed for eligibility to participate. Detailed explanation of the study's purposes and procedures as well as a copy of the Participant Information Sheet was provided to the patient and/or FC prior to obtaining their consent for participation in the study. Eligible participants were informed about the voluntary nature of the study and they were able to withdraw from the study at any time without compromising on the quality of care that would be rendered. Written informed consents were obtained from patients/ and/or their/ FCs. The questionnaires were administered by trained interviewers to eligible patients/ and/or FCs who are not able to read but able to understand their native language verbally in a quiet room at the outpatient clinics or inpatient wards. Clinical information of patients was collected directly from the medical record. The study was conducted from 1 April 2014 to 1 December 2016.

Ethical approval to conduct this study was obtained from the Centralized Institutional Review Board of the Singapore Health Services.

\section{Measures}

\section{Patients}

\section{Background information form}

The background information obtained from the patients included race, nationality, gender, marital status, education, housing type, employment status, tumour site, number of co-morbidities, clinical setting, and whether patients were receiving palliative care (under the care of palliative care physicians/ organizations). Functional status was measured by Karnofsky Performance Status (KPS) index [31].

\section{Comprehensive needs assessment tool (CNAT)}

Needs were assessed with the comprehensive needs assessment tool (CNAT) for cancer patients. The 59-item questionnaire measure 7 domains of need: (1) information and education (10 items), (2) psychological problems (10 items), (3) healthcare staff (8 items), (4) physical symptoms (12 items), (5) hospital facilities and services (8 items), (6) social and religious/spiritual support (5 items), and (7) practical support (6 items). Items are scored on a 4-point scale of severity according to the level of need: (1) No need help, (2) A little help needed, (3) Moderate help needed and, (4) A lot of help needed. The CNAT has good validity with a reported coefficient of reliability of Cronbach's alpha of between 0.80 and 0.937 [32].

\section{Caregiver's questionnaire}

1. The background information

The background information obtained from the patients' FCs included race, nationality, gender, marital status, education, housing type, employment status, relationship to patient, caregiving roles, assistance with caregiving, caregiver's medical condition, clinical setting, and whether patients were receiving palliative care. Functional status of the patients cared for was measured by Karnofsky Performance Status (KPS) index [31].

\section{Caregiver needs assessment}

We used the 41-item Comprehensive Needs Assessment Tool (CNAT-C) to assess the needs of FCs of cancer patients in 7 domains: (1) health and psychological problems (6 items), (2) family/ social support (5 items), (3) Healthcare staff (8 items), (4) information (8 items), (5) religious/ spiritual support (2 items), (6) hospital facilities and services (6 items), and (7) practical support (6 items). Each domain contains 2 to 8 items. Items are scored on a 4point scale of severity according to the level of need: (1) No need help, (2) A little help needed, (3) Moderate help needed and, (4) A lot of help needed. The CNAT-C has good validity with a reported coefficient of reliability of Cronbach's alpha of between 0.75 and 0.95 [33].

\section{Statistical methods}

The sample size is estimated to be 600 patients and 600 FCs. In order to compare the mean scores between 2 independent groups (inpatient versus SOC setting; with $\mathrm{PC}$ versus without $\mathrm{PC}$ ) using two-tailed t-test, a total sample size of 574 gives $90 \%$ power at $5 \%$ significance level, to detect an effect size as small as 0.3 for group size that may vary up to a 2:5 ratio. The estimated sample size is 600 considering there might be a small 
proportion $(<5 \%)$ of participants with incomplete filling of questionnaire.

Data were analysed for the entire cohort of respondents, and by difference in needs between cancer patients and FCs. The differences in needs were further analysed based on clinical significance and across settings (inpatients vs outpatients), care received (with or without PC), and KPS scores. As there is a paucity of local data on palliative care needs in patients with advanced cancer and FCs in Singapore, hence an exploratory comprehensive assessment of needs would add to the body of knowledge that is currently lacking.

Scoring of patients and caregivers needs were performed according to the guidelines set by each questionnaire. For both patients and caregivers, each item in the respective surveys reflects the specific level of needs of patients/caregivers in the previous month by "0 (No need help)", "1 (A little)", "2 (Moderately)", and "3 (A lot)". A higher score would then indicate higher needs. The subdomain scores are derived by computing the mean score of the questions in the subdomain followed by rescaling the scores to a $0-100$ scale. The CNAT total score is derived by computing the mean score of all the CNAT questions followed by rescaling the score to a $0-100$ scale.

Demographics and clinical characteristics were summarized using frequency and percentage for categorical variables, and median and range for continuous variables. ANOVA tests were carried out on the subdomain scores to compare the prevalence of needs between patients who received and didn't receive palliative care (under or not under the care of palliative team/ organisations), among patients with KPS score in the range of $0-40,50-70$ and $80-100$, and between patients with outpatient and inpatient clinical setting. Univariable and multivariable regression analysis were performed to assess the association between characteristics and total CNAT scores. Variable selection for multivariable analysis was performed using the backward elimination method, by optimizing the Akaike Information Criterion (AIC).

Statistical significance was assessed by two-sided $p$ value less than 0.05 . All statistical analyses were performed using R software (version 3.6.0).

\section{Results}

\section{Participants characteristics}

The data consisted of 599 patients with advanced cancer and 599 FCs recruited. Comparing advanced cancer patients with FCs, the demographics of patients appeared to be different from that of the FCs (Table 1). The FCs (median age 51 years) were younger than the patients (median age 62 years), and were mostly female (62.6\%) where the gender distribution of patients was quite balanced (49.2\% male and $50.8 \%$ female). Only $29.4 \%$ of patients were employed while $59.8 \%$ FCs were working and caregiving for the patients concurrently. The caregiving role was mainly undertaken by children or spouse (43.7 and $43.1 \%$ respectively). Most of the patients (97.2\%) and FCs (98.7\%) were aware of the cancer diagnosis.

Table 2 shows context of caregiving where only $30.1 \%$ of the FCs had previous caregiving experiences and only $7.7 \%$ received formal caregiving training despite $65.3 \%$ of the patients deeming themselves to require some assistance in their normal activities. Most FCs were involved in decision making (92.5\%) and providing emotional support $(98.8 \%)$.

\section{Needs of Cancer patients and their caregivers}

Tables 3 and 4 show the top rankings of needs of items in each domain by patients and their FCs according to their mean score respectively. The items "I needed information about financial support for patients, either from government and/ or private organisations (e.g. support for medical expenses)" and "I needed help with my economic burden due to this illness (treatment costs, loss of income)" were ranked as the top items for the domain "information" and "practical support" by the patients. While the FCs ranked "I needed information about financial support for medical expenses either from government and/ or private organisations" $(\bar{x}=1.22)$ and "I needed the treatment to be near home for the patient" $(\overline{\mathrm{x}}=1.06)$ are ranked as the top items for the domain "information" and "practical support" respectively. Overall, the item that had the highest need score in "information" domain for both patients and FCs was "financial support for patients, either from government and/ or private organizations.

Table 5 shows the total CNAT scores of FCs $(20.5 \pm$ 17.8) were higher than that of the patients $(14.1 \pm 14.7)$. Both patients and FCs had "information" and "practical support" in their top three domains of palliative care needs. The second highest domain of needs was "psychological problems" $(16.4 \pm 21.5)$ in patients and "health-care staff" $(23.4 \pm 26.5)$ in FCs.

Table 6 shows the difference of needs between cancer patients and their FCs in different clinical settings, with/ without palliative care and across different range of KPS. Under clinical setting, the inpatients $(19.2 \pm 16.4)$ and their FCs $(26.0 \pm 19.0)$ tend to have higher needs than the outpatients $(10.5 \pm 12.1)$ and their FCs $(14.7 \pm 14.3)$. In terms of palliative care, higher total CNAT score was observed in both patients $(16.6 \pm 12.9$ versus $13.3 \pm 15.2)$ and their FCs $(25.1 \pm 18.6$ versus $17.7 \pm 16.7)$ who received palliative care. For patients with palliative care, both FCs and patients had high needs in "Information" and "Practical support" domains. In terms of patients' 
Table 1 Sample characteristics

\begin{tabular}{|c|c|c|c|}
\hline & & Patients $(\boldsymbol{n}=599)$ & Caregivers $(\boldsymbol{n}=599)$ \\
\hline \multirow[t]{2}{*}{ Age } & Median (Q1,Q3) & $62.0(55.0,68.0)$ & $51.0(40.0,59.0)$ \\
\hline & Range & $24.0-91.0$ & $21.0-81.0$ \\
\hline \multirow[t]{2}{*}{ Clinical Setting } & SOC & $350(58.4 \%)$ & 294 (49.1\%) \\
\hline & Inpatient & $249(41.6 \%)$ & 305 (50.9\%) \\
\hline \multirow[t]{4}{*}{ Race } & Chinese & $495(82.6 \%)$ & 467 (78.0\%) \\
\hline & Malay & $67(11.2 \%)$ & $84(14.0 \%)$ \\
\hline & Indian & $25(4.2 \%)$ & $37(6.2 \%)$ \\
\hline & Others & $12(2.0 \%)$ & $11(1.8 \%)$ \\
\hline \multirow[t]{2}{*}{ Gender } & Male & $295(49.2 \%)$ & 224 (37.4\%) \\
\hline & Female & $304(50.8 \%)$ & $375(62.6 \%)$ \\
\hline \multirow[t]{4}{*}{ Marital Status } & Single & $78(13.0 \%)$ & $122(20.4 \%)$ \\
\hline & Married & $453(75.6 \%)$ & 467 (78.0\%) \\
\hline & Divorced & $20(3.3 \%)$ & $5(0.8 \%)$ \\
\hline & Widowed & $48(8.0 \%)$ & $5(0.8 \%)$ \\
\hline \multirow[t]{5}{*}{ Housing Type } & Don't wish to say & $4(0.7 \%)$ & $2(0.3 \%)$ \\
\hline & HDB 1 to 2 rooms & $42(7.0 \%)$ & $25(4.2 \%)$ \\
\hline & HDB 3 to 4 rooms & $293(48.9 \%)$ & $282(47.1 \%)$ \\
\hline & HDB 5 rooms and above & $171(28.5 \%)$ & 185 (30.9\%) \\
\hline & Private residential property & 89 (14.9\%) & $105(17.5 \%)$ \\
\hline \multirow[t]{2}{*}{ Employment Status } & Unemployed & $423(70.6 \%)$ & $241(40.2 \%)$ \\
\hline & Employed & $176(29.4 \%)$ & 358 (59.8\%) \\
\hline \multirow[t]{2}{*}{ Palliative Care } & With palliative care & $151(25.2 \%)$ & $222(37.1 \%)$ \\
\hline & Without palliative care & $448(74.8 \%)$ & 377 (62.9\%) \\
\hline \multirow[t]{2}{*}{ Paired patient/ caregiver } & Non-paired & $374(62.4 \%)$ & $374(62.4 \%)$ \\
\hline & Paired & $225(37.6 \%)$ & 225 (37.6\%) \\
\hline \multirow[t]{3}{*}{ Highest Education Level } & Primary and lower & $225(37.6 \%)$ & $122(20.4 \%)$ \\
\hline & Secondary and higher & $314(52.4 \%)$ & $303(50.6 \%)$ \\
\hline & University & $60(10.0 \%)$ & 174 (29.0\%) \\
\hline \multirow[t]{3}{*}{ KPS Scores } & KPS 0-40 & $100(16.7 \%)$ & $176(29.4 \%)$ \\
\hline & KPS 50-70 & $291(48.6 \%)$ & 275 (45.9\%) \\
\hline & KPS 80-100 & $208(34.7 \%)$ & 148 (24.7\%) \\
\hline \multirow[t]{3}{*}{ Awareness of Cancer $^{a}$} & No & $6(1.0 \%)$ & \\
\hline & Yes & $582(97.2 \%)$ & \\
\hline & Unsure & $11(1.8 \%)$ & \\
\hline \multirow[t]{3}{*}{ Receive Chemotherapy ${ }^{a}$} & No & $311(51.9 \%)$ & \\
\hline & Yes & $283(47.2 \%)$ & \\
\hline & Unsure & $5(0.8 \%)$ & \\
\hline \multirow[t]{3}{*}{ Receive Radiotherapy ${ }^{a}$} & No & $558(93.2 \%)$ & \\
\hline & Yes & $34(5.7 \%)$ & \\
\hline & Unsure & $7(1.2 \%)$ & \\
\hline \multirow[t]{4}{*}{ Cancer Type $^{a}$} & Colorectal & $121(20.2 \%)$ & \\
\hline & Lung & $106(18.0 \%)$ & \\
\hline & Breast & $92(15.6 \%)$ & \\
\hline & Gynaecological & $38(6.3 \%)$ & \\
\hline
\end{tabular}


Table 1 Sample characteristics (Continued)

\begin{tabular}{|c|c|c|c|}
\hline & & Patients $(\boldsymbol{n}=599)$ & Caregivers $(\boldsymbol{n}=599)$ \\
\hline & Head and neck & $26(4.3 \%)$ & \\
\hline & Pancreas & $26(4.3 \%)$ & \\
\hline & Kidney & $26(4.3 \% 0$ & \\
\hline & Upper gastrointestinal & $22(3.7 \%)$ & \\
\hline & Liver & $14(2.3 \%)$ & \\
\hline & Others & $128(21.3 \%)$ & \\
\hline \multirow[t]{7}{*}{ Relationship with Patient ${ }^{\mathrm{b}}$} & Spouse & & $258(43.1 \%)$ \\
\hline & Child & & $262(43.7 \%)$ \\
\hline & Parent & & $5(0.8 \%)$ \\
\hline & Sibling & & $38(6.3 \%)$ \\
\hline & Extended family (cousin, aunt) & & $32(5.3 \%)$ \\
\hline & Friend & & $2(0.3 \%)$ \\
\hline & Others & & $2(0.3 \%)$ \\
\hline \multirow[t]{4}{*}{ Aware of Diagnosis $^{b}$} & No & & $4(0.7 \%)$ \\
\hline & Yes & & $591(98.7 \%)$ \\
\hline & Unsure & & $4(0.7 \%)$ \\
\hline & Don't wish to say & & $0(0.0 \%)$ \\
\hline \multirow[t]{4}{*}{ Aware of Incurability ${ }^{b}$} & No & & $32(5.3 \%)$ \\
\hline & Yes & & $499(83.3 \%)$ \\
\hline & Unsure & & $59(9.8 \%)$ \\
\hline & Don't wish to say & & $9(1.5 \%)$ \\
\hline
\end{tabular}

Data was not collected from the caregivers

b Data was not collected from the patients

KPS scores, patients with lower KPS scores tend to have higher needs. Patients with $0-40$ KPS scores had the highest needs in the "psychological problems" domain followed by "practical support" domain.

Univariable and multivariable regression analysis were performed to assess the association between characteristics and total CNAT scores for patients (Table 7) and FCs (Table 8). Multivariable analysis results showed that younger age, inpatient setting, male gender, paired patients and FCs, higher education level and lower KPS scores were associated with higher needs in both patients and FCs. In addition, "Aware of Cancer" was selected for patients and "Employment Status" was included in the multivariable model for FCs. Patients who were unaware of cancer had much lower CNAT total scores, but the sample size was very small (6 out of 599 patients). On the other hand, FCs who were unemployed had higher needs after adjusting for other variables in the multivariable model. In terms of Education, both patients and FCs with secondary (had at least 10 years of basic education) and higher and university education had higher needs compared to patients/ FCs with primary education and lower. FCs had highest unmet needs in the "University" category" whereas patients had highest unmet needs in the "Secondary and higher" category.

\section{Discussion}

The results of this study show that patients with advanced cancer and their FCs have needs in all the 7 domains with different intensities. Since patients with advanced cancer suffer from several physical and psychological symptoms [34], it may be natural that they have more needs. However, in our study, FCs appeared to have more needs than patients (Table 5, higher mean scores in all domains). This result suggests that caregiving burden could be much higher than common general perception and that caregivers also have a lot of unmet needs. A study by Chang et al. [15] established that caregivers of terminal cancer patients were more burdened than patients.

The top needs were found in the domain of information for both patients and their FCs across all settings and irrespective of whether patients received palliative care. The need for information is well reported in the literature [8, 11, 27, 28, 35-37].

Information need related to financial support was positioned first by both patients and their FCs and 
Table 2 Context of caregiving

\begin{tabular}{|c|c|c|}
\hline Caregiving Variables & & n (\%) \\
\hline \multirow[t]{4}{*}{ Stop work to look after patient } & No & $494(82.5)$ \\
\hline & Partially & $26(4.3)$ \\
\hline & Yes, on unpaid leave & $22(3.7)$ \\
\hline & Yes, resigned & $57(9.5)$ \\
\hline \multirow[t]{3}{*}{ Physical caregiving } & No & $343(57.3)$ \\
\hline & Partially ${ }^{a}$ & $122(20.4)$ \\
\hline & Yes $^{\mathrm{b}}$ & $134(22.4)$ \\
\hline \multirow{3}{*}{$\begin{array}{l}\text { Hours spent in providing } \\
\text { physical care (if applicable) }\end{array}$} & Mean (SD) & $3.1(5.0)$ \\
\hline & Median (range) & $0.0(0.0-4.5)$ \\
\hline & Min - Max & $0.0-20.0$ \\
\hline \multirow[t]{4}{*}{ Financial caregiving } & Don't wish to disclose & $1(0.2)$ \\
\hline & No & $225(37.6)$ \\
\hline & Partially ${ }^{\mathrm{a}}$ & $191(31.9)$ \\
\hline & Yes $^{\mathrm{b}}$ & $182(30.4)$ \\
\hline \multirow[t]{3}{*}{ Emotional caregiving } & No & $7(1.2)$ \\
\hline & Partially ${ }^{\mathrm{a}}$ & $135(22.5)$ \\
\hline & Yes $^{\mathrm{b}}$ & $457(76.3)$ \\
\hline \multirow[t]{3}{*}{ Decision making } & No & $45(7.5)$ \\
\hline & Partially ${ }^{a}$ & $403(67.3)$ \\
\hline & Yes $^{\mathrm{b}}$ & $151(25.2)$ \\
\hline \multirow[t]{2}{*}{ Received formal caregiving training } & No & $553(92.3)$ \\
\hline & Yes & $46(7.7)$ \\
\hline \multirow{2}{*}{$\begin{array}{l}\text { Previous experience in providing } \\
\text { care for someone sick }\end{array}$} & No & $419(69.9)$ \\
\hline & Yes & $180(30.1)$ \\
\hline
\end{tabular}

a "Partially" referring to less than $50 \%$ involvement in caregiving role b "Yes" referring to at least $50 \%$ involvement in the caregiving role

assistance with economic burden caused by cancer was positioned second for patients and fifth for FCs respectively under the "practical support" domain. The financial concerns caused by cancer is well reported in the literature $[11,13,17,18,35,38-40]$ and financial distress in patients with advanced cancer is found to have a negative impact on their physical, emotional and social wellbeing [41]. Many of the patients in our study are elderly and unemployed, and many of their FCs are also unemployed. Findings also reveal that $17.5 \%$ of FCs' work was affected due to caring for the cancer patients and of these, 9.5\% resigned from their work. Literature reveals that many cancer patients and their FCs have difficulties maintaining work, which results in economic burden on the whole family [5, 11, 13, 16]. In Angioli et als' [5] study on the economic burden among $172 \mathrm{FCs}$ of patients with advanced ovarian cancer, the researchers established the mean cost for each caregiver was $€ 10,981$ annually. Overall, work productivity loss had a significant, direct relationship with anxiety, depression, disrupted schedule, and health problems, and caregiver perceived burden of financial problems. Their study did not take into account of the financial support that FCs provide to support their relatives' medical care which is common in the Asian setting where filial piety and family harmony obligate family members to assist with the financial burden which is evidenced in our study that $62 \%$ of caregivers provided financial support to the patients. This might reflect significant financial burden experienced by cancer patients and their FCs in Singapore in the current healthcare system. As such, active efforts to explore the financial challenges and concerns confronting both patients and their FCs in order to reduce the direct and indirect economic costs related to cancer is warranted to guide policy making. In addition, providing and developing further information and support strategies for both patients and their FCs based on identified needs in the interim is urgently needed.

Both patients and FCs identified practical support as the 3rd top domain of needs. Both groups wanted treatment to be near patients' home and needed transportation assistance for getting to and from the healthcare facility. The need for repeated visits for cancer treatment on an outpatient or inpatient basis makes distance an important issue with which the patients and their FCs must manage during the disease trajectory. Literature indicates that transportation is one of major barriers impacting healthcare access resulting in delayed or missed appointments or discontinuity in follow-up care, and affecting particularly those with lower income or the under/uninsured [42-44]. This may mean that transportation is a relatively high burden for both patients and FCs. Transportation need is usually under addressed by health care providers. Our findings demonstrate that in addition to financial assistance programmes, caregivers support programmes could include practical support aspects such as transportation services. Further studies are also needed to establish the factors that make transportation a barrier, the impact of transportation barriers and the types of interventions needed.

There is also a high level of needs in the health care staff domain identified by FCs across all settings as compared to patients. FCs want to see their doctor quickly and easily when needed. In our study, 93.5\% of FCs were involved in decision-making and this role inherently requires readily available access to the patients' doctor. The availability and accessibility of health care staff remains an important area of health service delivery, especially in the context of an increasing complex medical treatment environment [45]. A study of caregivers' needs in Korea established this as the top need [27] and another study in Iran also found out that health care staff need is the second commonest demand reported by caregivers [28]. Results reflected the gap between health care services provided and caregiver's experiences on 
Table 3 Top ranked mean score of individual CNAT question according to domain (Patients)

\begin{tabular}{ll}
\hline & Mean \\
Score \\
\hline
\end{tabular}

Information

1. I needed information about financial support for patients, 1.05 either from government and/ or private organisations (e.g. support for medical expenses).

2. I needed information about palliative care services

3. I needed guidelines or information about complementary 0.64 and alternative medicine

4. I needed information about correct diet (food to eat, food to avoid)

5. I needed information about the current status of my illness and its future course

Psychological problems

1. I needed help with worries that I would become a burden to others around me

2. I needed help with my concerns for the family

3. I needed help with worries about treatment sequelae

4. I needed help in coping with fear of recurrence

5. I needed help with accepting role changes at home, at work and/ or in society after this illness was diagnosed

Practical support

1. I needed help with my economic burden due to this illness (treatment costs, loss of income)

2. I needed treatment near my home

3. I needed transportation services for getting to and from the hospital

4. I needed accommodation services near the hospital where I was being treated

5. I needed someone to help me with housekeeping and/ or child care

Physical symptoms

1. I needed help with lack of energy and/ or fatigue

2. I needed help with trouble sleeping or oversleeping

3. I needed help with pain

4. I needed help with lack of appetite

5. I needed help with diarrhoea or constipation

Hospital facilities \& services

1. I needed rehabilitation medical services to help with functional recovery after treatment

2. I wished for a short waiting period between the reservation and the doctor appointment

3. I needed a designated hospital staff member who would be able to provide counselling for any concerns, and guidance with the course of my treatment, from the point of diagnosis to the period after the discharge.

4. I needed an opportunity to share experiences or information with other patients (e.g. patient support groups etc)

5. I wished to be treated in a pleasant environment

Health-care staff

Table 3 Top ranked mean score of individual CNAT question according to domain (Patients) (Continued)

\begin{tabular}{ll}
\hline & $\begin{array}{l}\text { Mean } \\
\text { Score }\end{array}$ \\
\hline $\begin{array}{l}\text { 1. I wished to be able to see the doctor in a quick and easy } \\
\text { way when in need }\end{array}$ & 0.63 \\
2. I wished my nurses to promptly attend to my discomfort & 0.38 \\
and pain & \\
3. I wished my nurses to explain any treatment or care that & 0.32 \\
was being given to me & \\
4. I wished my doctor to be easy, specific, and honest in & 0.32 \\
his/ her explanation & \\
5. I wished sincere interest and empathy from my nurse & 0.30 \\
Social/ religious/ spiritual support & \\
1. I needed help in finding the meaning of my situation \\
and in coming to terms with it
\end{tabular}

service delivery. Our findings also suggest that patients are relatively passive in the decision-making process and as such, it is necessary to include FCs during the treatment making process with the patients. This is supported by a study conducted in an Asian setting, where $97.2 \%$ of family members made decisions for patients [46].

Our study also revealed the psychosocial impact affecting the cancer patients (3rd top scores) and almost all (98.8\%) of FCs provide emotional support to the patients. This is on top of their need for help with concerns about the patients (top 6 need) and help with their own emotional feelings. Consistent with previous findings, patients and their FCs experienced a lot of emotional distress during the cancer trajectory and especially so for those at the advanced cancer stages [8, 25, 47, 48]. Given the psychological impact of cancer on patients and their FCs, understanding and addressing their psychological and emotional needs is needed in order to improve their well-being.

Both patients and FCs identified their need for guidelines or information about complementary and alternative medicine (CAM), as the 4th most important need. The interest in the use of CAM is not unexpected in the cancer trajectory especially when confronting the advanced stage or terminal stage. The hope for cure and the easily accessibility of CAM products may prove irresistible to these vulnerable patients and FCs. Surveys conducted in Singapore confirmed the interest in information relating to CAM $[35,36]$. A study conducted in 
Table 4 Top ranked mean score of individual CNAT question according to domain (FCs)

\begin{aligned} & \hline Mean \\ & Score \\ & \hline\end{aligned}

Information

1. I needed information about financial support for medical 1.22 expenses either from government and/ or private organisations

2. I needed guidelines or information about complementary 1.04 and alternative medicine

3. I needed information about caring for the patient (symptom management, diet, exercise, etc.)

4. I needed information about the current status of the patient's illness and its future course

5. I needed information about tests and treatment that the patient receives

Health-care staff

1. I needed to see the doctor quickly and easily when in need

2. I needed nurses to promptly attend to the patient's discomfort and pain

3. I needed the doctor to be clear, specific, and honest in his/ her explanation

4. I needed cooperation and communication among health- 0.68 care staff

5. I needed the nurses to explain treatment or care given to 0.67 the patient

Practical support

1. I needed the treatment to be near home for the patient

2. I needed help with the economic burden caused by cancer

3. I needed a transportation service for getting to and from the hospital

4. I needed accommodation services near the hospital where the patient was being treated

5. I needed assisted care in hospital or at home

1.06

1.01

0.71

Hospital facilities \& services

1. I needed a designated hospital staff member who would be able to provide counselling for any concerns, and guidance with the course of the treatment, from the point of diagnosis to the period after discharge.

2. I needed a space reserved for caregivers within the hospital

3. I needed a visiting nurse service for home

4. I needed guidance about hospital facilities and services

5. I needed the opportunity to share experiences or information with other caregivers

Health \& psychological problems

1. I needed help with concerns about the patient

2. I needed help with feelings of vague anxiety

3. I needed help with feelings of anger, irritability, or nervousness

4. I needed help with depression

5. I needed help with loneliness or feelings of isolation
Table 4 Top ranked mean score of individual CNAT question according to domain (FCs) (Continued)

\begin{tabular}{lc}
\hline & $\begin{array}{c}\text { Mean } \\
\text { Score }\end{array}$ \\
\hline $\begin{array}{l}\text { Family/ social support } \\
\text { 1. I needed help with patient over-dependence }\end{array}$ & 0.52 \\
2. I needed help with my own relaxation and my personal & 0.51 \\
$\quad$ life & \\
3. I needed help with difficulties in family relationships after & 0.34 \\
cancer diagnosis & \\
4. I needed help with the patient's lack of appreciation of & 0.29 \\
the caregiving & \\
5. I needed help with difficulties in interpersonal & 0.24 \\
relationships after cancer diagnosis & \\
Religious/ spiritual support & 0.34 \\
1. I needed help in finding the meaning of my situation \\
and coming to terms with it
\end{tabular}

Singapore showed high prevalence of CAM use (55\%) among cancer patients especially those with stage 4 disease while receiving chemotherapy or radiotherapy. Thirty-seven percent of patients believed CAM to be equally or more effective than conventional treatments [49]. However, the use of CAM in combination of conventional therapies is not without risks [50, 51], and therefore is a valid need that warrants attention.

In our study, we found that patients who received palliative care and their FCs have more needs than those who did not receive palliative care. Although, it can be expected that those who received palliative care are more ill (tended to be inpatients and lower KPS) and therefore have more needs, as early palliative care has been proven to improve the QOL of the patients with advanced cancer [52-56], we postulate that this may also imply that patients with advanced cancer were referred by their oncologists to palliative care physicians late in their cancer trajectory. This late referral may have resulted in patients who are more ill and therefore, have more needs and require more care. The findings that almost $75 \%$ of the patients group and almost $63 \%$ of the FCs group cared for patients who were not referred to palliative care physicians in spite of their advanced stage in cancer, and patients have also identified under the domain on "Information" as the top second information needs as "I needed information about palliative care services" may add credence to this view. In order to ascertain the real reason why patients and their FCs who received palliative care have more needs, further study would be needed as late referral to palliative care is associated with aggressive end of life treatment [55]. 
Table 5 Overall difference of needs between cancer patients and their caregivers

\begin{tabular}{llll}
\hline Patients' Domain & Mean (SD) & Caregivers' Domain & Mean (SD) \\
\hline Information & $19.5(22.6)$ & Information & 28.9 (27.0) \\
Psychological problems & $16.4(21.5)$ & Health-care staff & $23.4(26.5)$ \\
Practical support & $16.1(20.6)$ & Practical support & 23.4 (24.1) \\
Physical symptoms & $13.3(16.6)$ & Hospital facilities \& services & $19.1(21.3)$ \\
Hospital facilities \& services & $12.6(16.1)$ & Health \& psychological problems & $13.7(17.3)$ \\
Health-care staff & $11.0(18.3)$ & Family/ Social support & $12.7(17.9)$ \\
Social/ Religious/ Spiritual support & $5.4(13.0)$ & Religious/ Spiritual support & 9.7 (20.1) \\
Total CNAT Score & $14.1(14.7)$ & Total CNAT Score & $20.5(17.8)$ \\
\hline
\end{tabular}

Our study also revealed that the lower the KPS scores, the higher level of needs for both patients and their FCs. We postulate that because patients with lower KPS scores are less able to provide self-care due to their decreased functional abilities, they are more dependent on others to assist them in the activities of daily living (ADL), they tend to have more needs and those providing care to them will inadvertently have also more needs. Similarly, both inpatients groups of patients and their FCs have more needs as compared to outpatients. Mawardika et al. [57] reported that gynaecological cancer patients' physical and psychological supportive care is comparatively higher (44 times) for those receiving inpatient care than those receiving outpatient care. Besides, the financial cost associated with hospitalization is considerably higher than outpatient and as such, they logically have more needs. We also found that older patients tended to have more needs in the inpatients group. It may be that older patients tended to be more physically challenged and less likely to be employed, and therefore have more needs. In addition, female inpatients tended to have more unmet needs. The reason is unclear and the possible explanation being the traditional roles Asian women play in supporting the family. Being hospitalized may impact their ability to perform their functions well.

Our findings provide important information to assist in the identification of at-risk groups based on sociodemographic characteristics of both patient and their caregivers who warrants more attention.

\section{Practice implications}

Our study has important implications from both clinical and research perspectives. From the clinical perspective, findings from this study elucidate areas to attend to in clinical practice and the need for healthcare professionals to systematically assess patients' and FCs' problems (including caregivers' training needs as part of quality care for patients) and provide timely information and supportive care. In addition, our results highlight the importance of ensuring sufficient resources are allocated to the development of appropriate strategies such as providing and developing further information materials and support programmes and services to address the key areas of identified needs of patients with advanced cancer and their FCs. From a research perspective, our results suggest that more studies need to be done to establish the financial challenges and concerns confronting both patients and their FCs in order to reduce the direct and indirect economic costs related to cancer. In addition, as early palliative care has been proven to improve the QOL of the patients with advanced cancer, it is important to ascertain the reasons for late referral to palliative care. Finally, a periodic audit of the needs of patients with advanced cancer and their FCS and how well their needs are met should be conducted under a patient and family centered approach in order to understand and address their unique and evolving needs.

\section{Limitations}

Our study has some limitations. This was a cross-sectional study at a particular point in time does not describe the longitudinal trends in needs in the course of the disease trajectory. An additional limitation was the nonrandomized nature of sampling resulting in the possibility of selection bias as only patients and FCs who agreed to participate were recruited. Moreover, data on nonrespondents were not systematically collected and as such, the participants may not be representative of the general population of patients with advanced cancer and their FCs. Despite these limitations, our study was conducted in the largest public ambulatory cancer centre and the largest public hospital in Singapore and the large sample size with equal number of patients and FCs, with the use of standardized and validated questionnaires for both patients and their FCs should have mitigated these limitations. Additionally, we were also able to demonstrate the differences in needs based on sample (patients vs FCs), settings (inpatients vs outpatients), care received (palliative vs non-palliative), and KPI scores. Thus, we believe that the results can be generalized to other settings. 
Table 6 Difference of needs between cancer patients and caregivers

\begin{tabular}{|c|c|c|c|c|c|c|c|c|c|}
\hline \multirow{2}{*}{$\begin{array}{l}\text { Patient } \\
\text { Inpatient/ SOC } \\
\text { Setting }\end{array}$} & \multicolumn{3}{|l|}{ Mean (SD) } & \multirow[b]{2}{*}{$\begin{array}{l}\boldsymbol{p}- \\
\text { value }\end{array}$} & \multirow{2}{*}{$\begin{array}{l}\text { Caregivers } \\
\text { Inpatient/ SOC } \\
\text { Setting }\end{array}$} & \multicolumn{3}{|l|}{ Mean (SD) } & \multirow[b]{2}{*}{$\begin{array}{l}\boldsymbol{p} \text { - } \\
\text { value }\end{array}$} \\
\hline & $\begin{array}{l}\text { Inpatient } \\
\text { Setting }(\boldsymbol{n}= \\
249)\end{array}$ & \multicolumn{2}{|c|}{ SOC Setting $(\boldsymbol{n}=350)$} & & & $\begin{array}{l}\text { Inpatient } \\
\text { Setting }(\boldsymbol{n}= \\
305)\end{array}$ & \multicolumn{2}{|c|}{ SOC setting $(\boldsymbol{n}=294)$} & \\
\hline Information & $23.7(23.2)$ & \multicolumn{2}{|l|}{$16.6(21.7)$} & $\begin{array}{l}< \\
0.001\end{array}$ & $\begin{array}{l}\text { Health and } \\
\text { psychological } \\
\text { problems }\end{array}$ & $17.1(18.4)$ & \multicolumn{2}{|l|}{$10.2(15.2)$} & $\begin{array}{l}< \\
0.001\end{array}$ \\
\hline $\begin{array}{l}\text { Psychological } \\
\text { problems }\end{array}$ & $22.2(24.1)$ & \multicolumn{2}{|l|}{$12.4(18.4)$} & $\begin{array}{l}< \\
0.001\end{array}$ & $\begin{array}{l}\text { Family/ Social } \\
\text { support }\end{array}$ & $16.1(20.0)$ & \multicolumn{2}{|l|}{$9.2(14.5)$} & $\begin{array}{l}< \\
0.001\end{array}$ \\
\hline Health-care staff & $16.4(21.6)$ & \multicolumn{2}{|l|}{$7.1(14.4)$} & $\begin{array}{l}< \\
0.001\end{array}$ & Health-care staff & $30.2(28.9)$ & \multicolumn{2}{|l|}{$16.3(21.6)$} & $\begin{array}{l}< \\
0.001\end{array}$ \\
\hline Physical symptoms & $19.0(18.7)$ & \multicolumn{2}{|l|}{$9.3(13.5)$} & $\begin{array}{l}< \\
0.001\end{array}$ & Information & $35.1(27.8)$ & \multicolumn{2}{|l|}{$22.3(24.5)$} & $\begin{array}{l}< \\
0.001\end{array}$ \\
\hline $\begin{array}{l}\text { Hospital facilities } \\
\text { and services }\end{array}$ & $17.7(18.6)$ & \multicolumn{2}{|l|}{$9.1(12.9)$} & $\begin{array}{l}< \\
0.001\end{array}$ & $\begin{array}{l}\text { Religious/Spiritual } \\
\text { support }\end{array}$ & $12.3(22.6)$ & \multicolumn{2}{|l|}{$7.0(16.6)$} & 0.001 \\
\hline $\begin{array}{l}\text { Social/ Religious/ } \\
\text { Spiritual support }\end{array}$ & $7.4(15.9)$ & \multicolumn{2}{|l|}{$4.0(10.3)$} & 0.002 & $\begin{array}{l}\text { Hospital facilities } \\
\text { and services }\end{array}$ & $25.2(23.1)$ & \multicolumn{2}{|l|}{$12.8(17.1)$} & $\begin{array}{l}< \\
0.001\end{array}$ \\
\hline Practical support & $23.2(23.9)$ & \multicolumn{2}{|l|}{$11.1(16.1)$} & $\begin{array}{l}< \\
0.001\end{array}$ & Practical support & $30.4(25.8)$ & \multicolumn{2}{|l|}{$16.1(19.6)$} & $\begin{array}{l}< \\
0.001\end{array}$ \\
\hline Total score & $19.2(16.4)$ & \multicolumn{2}{|l|}{$10.5(12.1)$} & $\begin{array}{l}< \\
0.001\end{array}$ & Total score & $26.0(19.0)$ & \multicolumn{2}{|l|}{$14.7(14.3)$} & $\begin{array}{l}< \\
0.001\end{array}$ \\
\hline $\begin{array}{l}\text { With/ Without } \\
\text { Palliative Care }\end{array}$ & $\begin{array}{l}\text { With PC } \\
(n=151)\end{array}$ & \multicolumn{2}{|c|}{ Without PC $(n=448)$} & $\begin{array}{l}p- \\
\text { value }\end{array}$ & $\begin{array}{l}\text { With/ Without } \\
\text { Palliative Care }\end{array}$ & $\begin{array}{l}\text { With PC } \\
(n=222)\end{array}$ & \multicolumn{2}{|l|}{$\begin{array}{l}\text { Without PC } \\
(n=377)\end{array}$} & $\begin{array}{l}p- \\
\text { value }\end{array}$ \\
\hline Information & $21.1(21.7)$ & \multicolumn{2}{|l|}{$19.0(22.9)$} & 0.327 & $\begin{array}{l}\text { Health and } \\
\text { psychological } \\
\text { problems }\end{array}$ & $16.3(17.2)$ & \multicolumn{2}{|l|}{$12.2(17.1)$} & 0.004 \\
\hline $\begin{array}{l}\text { Psychological } \\
\text { problems }\end{array}$ & $18.8(21.4)$ & \multicolumn{2}{|l|}{$15.6(21.5)$} & 0.112 & $\begin{array}{l}\text { Family/ Social } \\
\text { support }\end{array}$ & $15.0(19.0)$ & \multicolumn{2}{|l|}{$11.4(17.0)$} & 0.017 \\
\hline Health-care staff & $12.4(17.5)$ & \multicolumn{2}{|l|}{$10.5(18.6)$} & 0.259 & Health-care staff & $29.1(29.2)$ & $20.0(24.2)$ & & $\begin{array}{l}< \\
0.001\end{array}$ \\
\hline Physical symptoms & $16.5(14.8)$ & $12.2(17.0)$ & & 0.006 & Information & $33.9(27.3)$ & $25.9(26.3)$ & & $\begin{array}{l}< \\
0.001\end{array}$ \\
\hline $\begin{array}{l}\text { Hospital facilities } \\
\text { and services }\end{array}$ & $15.6(15.9)$ & $11.6(16.1)$ & & 0.008 & $\begin{array}{l}\text { Religious/Spiritual } \\
\text { support }\end{array}$ & $12.5(22.8)$ & $8.1(18.2)$ & & 0.01 \\
\hline $\begin{array}{l}\text { Social/ Religious/ } \\
\text { Spiritual support }\end{array}$ & $5.4(11.6)$ & $5.4(13.5)$ & & 0.981 & $\begin{array}{l}\text { Hospital facilities } \\
\text { and services }\end{array}$ & $23.5(22.2)$ & $16.5(20.4)$ & & $\begin{array}{l}< \\
0.001\end{array}$ \\
\hline Practical support & $21.6(22.1)$ & $14.3(19.7)$ & & $\begin{array}{l}< \\
0.001\end{array}$ & Practical support & $30.8(26.2)$ & $19.0(21.6)$ & & $\begin{array}{l}< \\
0.001\end{array}$ \\
\hline Total score & $16.6(12.9)$ & $13.3(15.2)$ & & 0.016 & Total score & $25.1(18.6)$ & $17.7(16.7)$ & & $\begin{array}{l}< \\
0.001\end{array}$ \\
\hline KPS & $\begin{array}{l}\text { KPS 0-40 } \\
(n=100)\end{array}$ & $\begin{array}{l}\text { KPS 50-70 } \\
(n=291)\end{array}$ & $\begin{array}{l}\text { KPS 80-100 } \\
(n=208)\end{array}$ & $\begin{array}{l}p- \\
\text { value }\end{array}$ & KPS & $\begin{array}{l}\text { KPS 0-40 } \\
(n=176)\end{array}$ & $\begin{array}{l}\text { KPS 50-70 } \\
(n=275)\end{array}$ & $\begin{array}{l}\text { KPS 80-100 } \\
(n=148)\end{array}$ & $\begin{array}{l}p- \\
\text { value }\end{array}$ \\
\hline Information & $23.0(20.3)$ & $19.6(23.3)$ & $17.7(22.5)$ & 0.151 & $\begin{array}{l}\text { Health and } \\
\text { psychological } \\
\text { problems }\end{array}$ & $17.6(17.8)$ & $14.2(18.4)$ & $8.2(12.4)$ & $\begin{array}{l}< \\
0.001\end{array}$ \\
\hline $\begin{array}{l}\text { Psychological } \\
\text { problems }\end{array}$ & $27.3(24.1)$ & $16.0(21.3)$ & $11.8(18.4)$ & $\begin{array}{l}< \\
0.001\end{array}$ & $\begin{array}{l}\text { Family/ Social } \\
\text { support }\end{array}$ & $17.4(20.2)$ & $12.9(18.6)$ & $6.7(10.2)$ & $\begin{array}{l}< \\
0.001\end{array}$ \\
\hline Health-care staff & $13.9(18.1)$ & $11.4(18.9)$ & $9.1(17.5)$ & 0.089 & Health-care staff & $29.1(28.7)$ & $23.3(25.8)$ & $16.8(23.4)$ & $\begin{array}{l}< \\
0.001\end{array}$ \\
\hline Physical symptoms & $21.5(16.8)$ & $13.0(15.5)$ & $9.8(16.6)$ & $\begin{array}{l}< \\
0.001\end{array}$ & Information & $34.7(27.0)$ & $28.6(27.2)$ & $22.3(25.2)$ & $\begin{array}{l}< \\
0.001\end{array}$ \\
\hline $\begin{array}{l}\text { Hospital facilities } \\
\text { and services }\end{array}$ & $17.0(16.0)$ & $13.5(16.4)$ & $9.4(15.1)$ & $\begin{array}{l}< \\
0.001\end{array}$ & $\begin{array}{l}\text { Religious/ Spiritual } \\
\text { support }\end{array}$ & $12.6(22.9)$ & $9.2(19.3)$ & $7.2(17.5)$ & 0.047 \\
\hline $\begin{array}{l}\text { Social/ Religious/ } \\
\text { Spiritual support }\end{array}$ & $6.3(14.7)$ & $5.5(12.5)$ & $4.9(13.0)$ & 0.65 & $\begin{array}{l}\text { Hospital facilities } \\
\text { and services }\end{array}$ & $25.4(22.9)$ & $18.8(21.2)$ & $12.1(16.8)$ & $\begin{array}{l}< \\
0.001\end{array}$ \\
\hline
\end{tabular}


Table 6 Difference of needs between cancer patients and caregivers (Continued)

\begin{tabular}{|c|c|c|c|c|c|c|c|c|c|}
\hline \multirow{2}{*}{$\begin{array}{l}\text { Patient } \\
\text { Inpatient/ SOC } \\
\text { Setting }\end{array}$} & \multicolumn{3}{|l|}{ Mean (SD) } & \multirow[b]{2}{*}{$\begin{array}{l}\boldsymbol{p} \text { - } \\
\text { value }\end{array}$} & \multirow{2}{*}{$\begin{array}{l}\text { Caregivers } \\
\text { Inpatient/ SOC } \\
\text { Setting }\end{array}$} & \multicolumn{3}{|l|}{ Mean (SD) } & \multirow[b]{2}{*}{$\begin{array}{l}\boldsymbol{p}^{-} \\
\text {value }\end{array}$} \\
\hline & $\begin{array}{l}\text { Inpatient } \\
\text { Setting }(\boldsymbol{n}= \\
249)\end{array}$ & SOC Settin & $n=350)$ & & & $\begin{array}{l}\text { Inpatient } \\
\text { Setting }(\boldsymbol{n}= \\
305)\end{array}$ & SOC settin & $n=294)$ & \\
\hline Practical support & $24.1(22.4)$ & $17.6(21.5)$ & $10.3(16.3)$ & $\begin{array}{l}< \\
0.001\end{array}$ & Practical support & $33.2(24.5)$ & $23.1(24.7)$ & $12.3(16.3)$ & $\begin{array}{l}< \\
0.001\end{array}$ \\
\hline Total score & $20.1(13.9)$ & $14.3(14.6)$ & $11.0(14.3)$ & $\begin{array}{l}< \\
0.001\end{array}$ & Total score & $26.3(18.2)$ & $20.4(18.0)$ & 13.6 (13.9) & $\begin{array}{l}< \\
0.001\end{array}$ \\
\hline
\end{tabular}

Table 7 Predictors of needs based on demographic data (Patient)

\begin{tabular}{|c|c|c|c|c|c|c|}
\hline \multicolumn{7}{|c|}{ Univariable and multivariable linear regression analysis on CNAT Total Scores (Patient) } \\
\hline \multicolumn{2}{|l|}{ Dependent: CNAT_Total } & \multirow{2}{*}{$\frac{\text { No. }}{\text { NA }}$} & \multirow{2}{*}{$\begin{array}{l}\text { Coefficient }(95 \% \mathrm{Cl}) \\
-0.33(-0.44 \text { to }-0.22)\end{array}$} & \multirow{2}{*}{$\frac{P(\text { wald })}{<0.001}$} & \multirow{2}{*}{$\begin{array}{l}\text { Adjusted Coefficient }(95 \% \mathrm{Cl}) \\
-0.31(-0.42 \text { to }-0.20)\end{array}$} & \multirow{2}{*}{$\frac{P(\text { wald })}{<0.001}$} \\
\hline Age & {$[24,91]$} & & & & & \\
\hline \multirow[t]{2}{*}{ Clinical Setting } & Inpatient & 249 & 1 & & & \\
\hline & SOC & 350 & $-8.78(-11.07$ to -6.49$)$ & $<0.001$ & $-6.59(-9.29$ to -3.90$)$ & $<0.001$ \\
\hline \multirow[t]{4}{*}{ Race } & Chinese & 495 & 1 & & & \\
\hline & Indian & 25 & $0.38(-5.51$ to 6.27$)$ & 0.899 & & \\
\hline & Malay & 67 & 5.78 (2.04 to 9.52$)$ & 0.003 & & \\
\hline & Others & 12 & 0.79 (-7.60 to 9.19) & 0.853 & & \\
\hline \multirow[t]{2}{*}{ Gender } & Female & 304 & 1 & & 1 & \\
\hline & Male & 295 & $0.90(-1.47$ to 3.26$)$ & 0.457 & 3.14 (0.91 to 5.36$)$ & 0.006 \\
\hline \multirow[t]{2}{*}{ Employment Status } & Employed & 176 & 1 & & & \\
\hline & Unemployed & 423 & $-1.30(-3.89$ to 1.29$)$ & 0.325 & & \\
\hline \multirow[t]{3}{*}{ Aware of Cancer } & Yes & 582 & 1 & & 1 & \\
\hline & No & 6 & $-9.22(-21.05$ to 2.61$)$ & 0.126 & $-11.30(-22.26$ to -0.34$)$ & 0.043 \\
\hline & Unsure & 11 & $-5.99(-14.76$ to 2.79$)$ & 0.181 & $-2.66(-10.81$ to 5.48$)$ & 0.521 \\
\hline \multirow[t]{3}{*}{ Receive Chemotherapy } & Yes & 283 & 1 & & & \\
\hline & No & 311 & $-0.14(-2.52$ to 2.24$)$ & 0.908 & & \\
\hline & Unsure & 5 & $-4.95(-18.00$ to 8.10$)$ & 0.456 & & \\
\hline \multirow[t]{3}{*}{ Receive Radiotherapy } & Yes & 34 & 1 & & & \\
\hline & No & 558 & $-7.56(-12.63$ to -2.48$)$ & 0.004 & & \\
\hline & Unsure & 7 & $-10.86(-22.78$ to 1.06$)$ & 0.074 & & \\
\hline \multirow[t]{2}{*}{ Palliative Care } & With Palliative Care & 151 & 1 & & & \\
\hline & Without Palliative Care & 448 & $-3.33(-6.04$ to -0.62$)$ & 0.016 & & \\
\hline \multirow[t]{2}{*}{ Paired with Caregiver } & Non-paired & 374 & 1 & & 1 & \\
\hline & Paired & 225 & 0.55 (-1.89 to 2.99$)$ & 0.66 & 3.20 (0.91 to 5.49$)$ & 0.006 \\
\hline \multirow[t]{3}{*}{ Education } & Primary and lower & 225 & 1 & & 1 & \\
\hline & Secondary and above & 314 & 3.05 (0.53 to 5.57$)$ & 0.018 & 3.19 (0.81 to 5.56$)$ & 0.009 \\
\hline & University & 60 & $1.34(-2.85$ to 5.52$)$ & 0.53 & $1.80(-2.16$ to 5.77$)$ & 0.373 \\
\hline \multirow[t]{5}{*}{ Cancer Type } & Breast & 92 & 1 & & & \\
\hline & Colorectal & 121 & $-2.64(-6.63$ to 1.36$)$ & 0.195 & & \\
\hline & Lung & 106 & $-0.37(-4.48$ to 3.75$)$ & 0.861 & & \\
\hline & Multiple primary & 20 & $-4.85(-11.98$ to 2.27$)$ & 0.182 & & \\
\hline & Others & 260 & $-2.38(-5.89$ to 1.12$)$ & 0.182 & & \\
\hline KPS & {$[20,90]$} & NA & $-0.18(-0.25$ to -0.12$)$ & $<0.001$ & $-0.13(-0.20$ to -0.06$)$ & $<0.001$ \\
\hline
\end{tabular}


Table 8 Predictors of needs based on demographic data (Caregiver)

\begin{tabular}{|c|c|c|c|c|c|c|}
\hline \multicolumn{7}{|c|}{ Univariable and multivariable linear regression analysis on CNAT Total Scores (Caregiver) } \\
\hline Dependent: CNAT_Total & & No. & Coefficient $(95 \% \mathrm{Cl})$ & $P($ wald $)$ & Adjusted Coefficient (95\%Cl) & $P($ wald $)$ \\
\hline Age & {$[21,81]$} & NA & $-0.18(-0.29$ to -0.08$)$ & 0.001 & $-0.13(-0.24$ to -0.02$)$ & 0.022 \\
\hline \multirow[t]{2}{*}{ Clinical Setting } & Inpatient & 305 & 1 & & 1 & \\
\hline & SOC & 294 & $-11.23(-13.94$ to -8.53$)$ & $<0.001$ & $-7.07(-10.31$ to -3.84$)$ & $<0.001$ \\
\hline \multirow[t]{4}{*}{ Race } & Chinese & 467 & 1 & & & \\
\hline & Indian & 37 & $5.13(-0.82$ to 11.08$)$ & 0.091 & & \\
\hline & Malay & 84 & $1.54(-2.59$ to 5.67$)$ & 0.464 & & \\
\hline & Others & 11 & $5.84(-4.79$ to 16.46$)$ & 0.281 & & \\
\hline \multirow[t]{2}{*}{ Gender } & Female & 375 & 1 & & 1 & \\
\hline & Male & 224 & $1.92(-1.02$ to 4.86$)$ & 0.201 & $2.12(-0.69$ to 4.93$)$ & 0.14 \\
\hline \multirow[t]{2}{*}{ Employment Status } & Employed & 358 & 1 & & 1 & \\
\hline & Unemployed & 241 & $0.36(-2.54$ to 3.27$)$ & 0.806 & 2.15 (-0.86 to 5.16$)$ & 0.16 \\
\hline \multirow[t]{3}{*}{ Aware of Diagnosis } & Yes & 591 & 1 & & & \\
\hline & No & 4 & $-1.98(-19.51$ to 15.54$)$ & 0.824 & & \\
\hline & Unsure & 4 & $-2.39(-19.91$ to 15.13$)$ & 0.789 & & \\
\hline \multirow[t]{4}{*}{ Aware of Incurability } & Yes & 499 & 1 & & & \\
\hline & No & 32 & $-7.28(-13.61$ to -0.94$)$ & 0.025 & & \\
\hline & Unsure & 59 & $2.70(-2.08$ to 7.49$)$ & 0.268 & & \\
\hline & Don't wish to say & 9 & $-2.64(-14.33$ to 9.05$)$ & 0.658 & & \\
\hline \multirow[t]{2}{*}{ Palliative Care } & With Palliative Care & 222 & 1 & & & \\
\hline & Without Palliative Care & 377 & $-7.34(-10.23$ to -4.45$)$ & $<0.001$ & & \\
\hline \multirow[t]{2}{*}{ Paired with Patient } & Non-paired & 374 & 1 & & 1 & \\
\hline & Paired & 225 & $-8.42(-11.29$ to -5.55$)$ & $<0.001$ & $-3.98(-7.00$ to -0.97$)$ & 0.01 \\
\hline \multirow[t]{3}{*}{ Education } & Primary and lower & 122 & 1 & & 1 & \\
\hline & Secondary and above & 303 & 3.81 (0.10 to 7.53$)$ & 0.044 & 4.51 (0.91 to 8.11$)$ & 0.014 \\
\hline & University & 174 & 6.69 (2.60 to 10.78$)$ & 0.001 & 5.92 (1.68 to 10.15$)$ & 0.006 \\
\hline KPS & {$[10,90]$} & NA & $-0.25(-0.32$ to -0.19$)$ & $<0.001$ & $-0.12(-0.20$ to -0.04$)$ & 0.004 \\
\hline
\end{tabular}

\section{Conclusion}

In summary, our study revealed that both patients and their FCs have many needs irrespective of their clinical settings. The top needs were found in the domain of information for both patients and their FCs across all settings and irrespective of whether patients received palliative care. The top need for both patients and their FCs relates to information about financial support suggesting the financial burden they are bearing and an area that warrants attention and support both by healthcare providers and the policy makers. In addition, FCs also tended to have more unmet needs than patients especially in the area of practical, emotional and psychological support, and quick access to healthcare professionals.

This study contributes to the growing literature of needs of patients with advanced cancer and their FCs and suggests that in order to deliver quality care to cancer patients, it is important to ensure that their FCs' needs are also not neglected.

\section{Abbreviations}

FC: Family caregivers; CNAT: Comprehensive Needs Assessment Tool; CNATC: Comprehensive Needs Assessment Tool for Cancer Caregivers; KPS: Karnofsky Performance Status; ANOVA: Analysis of variance; AIC: Akaike Information Criterion; CAM: Complementary and alternative medicine; ADL: Activities of daily living

\section{Acknowledgements}

We express appreciation to Yin Bun, Weng Kit, Geok Ling, participants in this study and the patients they care for. Appreciation is also extended to May Jin for the administrative support rendered.

\section{Authors' contributions}

GSYP conceptualised this study and developed the methodology. GSYP and ACPY obtained funding for this study. ACPY provided the resources for the study. YYW, DLQ and FTP conducted the investigation. SZ and CL performed validation and statistical analysis. GPC and SZ analysed the data. YYW handled data curation. GPC and GMY wrote the manuscript. GSYP and PSHN supervised the study. All authors have read and approved the manuscript.

\section{Authors' information}

1 CEIS (Research \& Data), National Cancer Centre Singapore, Singapore, Singapore. 2 medical services, Assisi hospice, Singapore, Singapore. 3 division of supportive and palliative care, National Cancer Centre Singapore, Singapore, Singapore. 4 division of clinical trails and epidemiological 
sciences, National Cancer Centre Singapore, Singapore, Singapore. 5 quality department, Assisi hospice, Singapore, Singapore. 6 Lien Centre palliative care, Singapore, Singapore

\section{Funding}

This study was funded by Singapore Millennium Foundation (2nd Grant Call). Singapore Millennium Foundation has no direct role in the design, conduct and analysis of the study.

\section{Availability of data and materials}

The datasets used and/or analysed during the current study available from the corresponding author on reasonable request.

\section{Ethics approval and consent to participate}

Ethical approval to conduct this study was obtained from the Centralized Institutional Review Board of the Singapore Health Services. Detailed explanation of the study purpose and procedure as well as a copy of the Participant Information Sheet was provided to the patient and/or FC prior to obtaining written consent to participate in the study. Eligible participants were informed about the voluntary nature of the study and they were able to withdraw from the study at any time without compromising on the quality of care that would be rendered.

\section{Consent for publication}

Not applicable.

\section{Competing interests}

The authors have no conflict of interest to declare.

\section{Author details}

'CEIS (Research \& Data), National Cancer Centre Singapore, 11 Hospital Crescent, Singapore, Singapore 169610, Singapore. ${ }^{2}$ Medical Services, Assisi Hospice, Singapore, Singapore. ${ }^{3}$ Division of Supportive and Palliative Care, National Cancer Centre Singapore, Singapore, Singapore. ${ }^{4}$ Division of Clinical Trails and Epidemiological Sciences, National Cancer Centre Singapore, Singapore, Singapore. ${ }^{5}$ Quality department, Assisi Hospice, Singapore, Singapore. ${ }^{6}$ Lien Centre Palliative Care, Singapore, Singapore.

\section{Received: 4 November 2019 Accepted: 29 July 2020}

\section{Published online: 15 August 2020}

\section{References}

1. Kim YA, Yun YH, Chang YJ, Lee J, Kim MS, Lee HS, et al. Employment status and work-related difficulties in lung cancer survivors compared with the general population. Ann Surg. 2014;259:569-75.

2. Wilson SE, Anderson MR, Meischke H. Meeting the needs of rural breast cancer survivors: what still needs to be done? J Women's Health GenderBased Med. 2000:9:667.

3. Ochayon L, Zelker R, Kaduri L, Kadmon I. Relationship between severity of symptoms and quality of life in patients with breast cancer receiving adjuvant hormonal therapy. Oncol Nurs Forum. 2010;37:349-58.

4. Kale HP, Carroll NV. Self-reported financial burden of cancer care and its effect on physical and mental health-related quality of life among US cancer survivors. Cancer. 2016;122:1283-9.

5. Angioli R, Capriglione S, Aloisi A, Miranda A, de Cicco NC, Terranova C, et al. Economic impact among family caregivers of patients with advanced ovarian cancer. Int J Gynecol Cancer. 2015;25(8):1541-6.

6. Honea NJ. Caregiver Burden. In: A Guide to Oncology Symptom Management. 2nd ed. Pennsylvania: Oncology Nursing Society; 2015. p. 143-69

7. Given BA, Given CW, Sherwood P. The challenge of quality cancer care for family caregivers. Semin Oncol Nurs. 2012;28(4):205-12.

8. Oechsle K. Current advances in palliative \& hospice care: problems and needs of relatives and family caregivers during palliative and hospice care an overview of current literature. Med Sci. 2019;7(43):1-16.

9. Soylu C, Ozaslan E, Karaca H, Ozkan M. Psychological distress and loneliness in caregiver of advanced oncological inpatients. J Health Psychol. 2016; 21(9):1896-906.

10. Fujinami R, Sun V, Zachariah F, Uman G, Grant M, Ferrell B. Family caregivers' distress levels related to quality of life, burden, and preparedness. Psychooncology. 2015;24(1):54-62.
11. Lund $L$, Ross $L$, Peterson MA, Groenvold M. Cancer caregiving tasks and consequences and their associations with caregiver status and the caregiver's relationship to the patient: a survey. BMC Cancer. 2014;14:541.

12. Heckel L, Fennell KM, Reynolds J, Osborne RH, Chirgwin J, Botti M, et al. Unmet needs and depression among carers of people newly diagnosed with cancer. Eur J Cancer. 2015;51(14):2049-57.

13. Rhee YS, Yun YH, Park S, Shin DO, Lee KM, Yoo HJ, et al. Depression in family caregivers of cancer patients: the feeling of burden as a predictor of depression. J Clin Oncol. 2008;26(36):5890-5.

14. Grunfeld E, Coyle D, Whelan T, Clinch J, Reyno L, Earle CC, et al. Family caregiver burden: results of a longitudinal study of breast cancer patients and their principal caregivers. CMAJ. 2004;170(12):1795-801.

15. Chang YJ, Kwon YC, Lee WJ, Do YR, Seok LK, Kim HT, et al. Burdens, needs and satisfaction of terminal cancer patients and their caregivers. Asian Pac J Cancer Prev. 2013;14(1):209-16.

16. Chen SC, Tsai MC, Liu CL, Yu WP, Liao CT, Chang JTC. Support needs of patients with oral cancer and burden to their family caregivers. Cancer Nurs. 2009;32(6):473-81.

17. Chua GP, Ng QS, Tan HK, Ong WS. Caregivers of cancer patients in Singapore: what are their unmet needs and quality of life? Int J Oncol Res. Under review.

18. Kim Y, Kashy DA, Spillers RL, Evans TV. Needs assessment of family caregivers of cancer survivors: three cohorts comparison. Psycho-Oncology. 2010;19(6):573-82.

19. Lambert SD, Harrison JD, Smith E, Bonevski B, Carey M, Lawsin C, et al. The unmet needs of partners and caregivers of adults diagnosed with cancer: a systematic review. BMJ Support Palliat Care. 2012;2(3):224-30.

20. Department of Statistics Singapore. Singapore Residents by Age Group, Ethnic Group and Sex. Department of Statistics Singapore; 2019. Available from: https://www.tablebuilder.singstat.gov.sg/publicfacing/createDataTable. action? refld=14911. Accessed on 3 Mar 2020.

21. Goh SSL. Singapore takes six steps forward in 'the quality of death index' rankings. APJON. 2018;5(1):21-5.

22. World Health Organisation (WHO). WHO definition of palliative care. World Health Organisation; 2020. Available from: http://www.who.int/cancer/ palliative/definition/en/. Accessed on 10 May 2020.

23. Australian Medical Association. Palliative approach in residential aged care 2015. 2015. Available from: https://ama.com.au/position-statement/palliativeapproach-residential-aged-care-2015. Accessed on 30 Sept 2019.

24. Lien Centre for Palliative Care. Report on the national strategy for palliative care. Ministry of Health; 2011. Available from: https://singaporehospice.org. sg/site2019/wp-content/uploads/Report_on_National_Strategy_for_ Palliative_Care-5Jan2012.pdf. Accessed on 10 May 2020.

25. Sklenarova H, Krumpelmann A, Haun MW, Friederich HC, Huber J, Thomas $M$, et al. When do we need to care about the caregiver? Supportive care needs, anxiety, and depression among informal caregivers of patients with cancer and cancer survivors. Cancer. 2015;121(9):1513-9.

26. Aoun SM, Deas K, Howting D, Lee G. Exploring the support needs of family caregivers of patients with brain cancer using the CSNAT: a comparative study with other cancer groups. PLoS One. 2015:10(12):e0145106.

27. Kim H, Yi M. Unmet needs and quality of life of family caregivers of cancer patients in South Korea. Asia Pac J Oncol Nurs. 2015;2(3):152-9.

28. Ashrafian S, Feizollahzadeh $H$, Rahmani A, Davoodi A. The unmet needs of the family caregivers of patients with cancer visiting a referral hospital in Iran. Asia Pac J Oncol Nurs. 2018;5:342-52

29. Chua CKT, Wu JT, Wong YY, Qu LM, Tan YY, Neo PSH, et al. Caregiving and its resulting effects - the care study to evaluate the effects of caregiving on caregivers of patients with advanced cancer in Singapore. Cancers. 2016; 8(11):105

30. Lim HA, Tan JYS, Chua J, Yoong RKL, Lim SE, Kua EH, et al. Quality of life of family caregivers of cancer patients in Singapore and globally. Singap Med J. 2017;58(5):258-61.

31. National Palliative Care Research Center. Measurement and evaluation tools. 2013. Available from: http://www.npcrc.org/files/news/karnofsky performance_scale.pdf. Accessed on 26 Sept 2019.

32. Yang GMJ, Pang GSY, Lee GL, Neo PSH, Wong YY, Qu DL, et al. Validation of the comprehensive needs assessment tool in patients with advanced cancer. Indian J Palliat Care. 2019;25(3):374-8.

33. Yang GMJ, Pang GSY, Lee GL, Neo PSH, Wong YY, Qu DL, et al. Validation of the English and translated Chinese version for the comprehensive needs assessment tool for cancer caregivers (CNAT-C). Progress Palliative Care. 2019;25(3):374-8. 
34. Lavdaniti M, Fradelos EC, Troxoutsou K, Zioga E, Mitsi D, Alikari V, et al. Symptoms in advanced cancer patients in a Greek hospital: a descriptive study. Asian Pac J Cancer Prev. 2018;19(4):1047-52.

35. Chua GP, Tan HK, Gandhi M. What information do cancer patients want and how well are their needs being met? Ecancermedicalscience. 2018;12:873. https://doi.org/10.3332/ecancer.2018.873.

36. Chua GP, Tan HK, Gandhi M. Information sources and online information seeking behaviours of cancer patients in Singapore. Ecancermedicalscience. 2018;12:880. https://doi.org/10.3332/ecancer.2018.880

37. Chen SC. Information needs and information sources of family caregivers of cancer patients. Aslib J Information. 2014;66(6):623-39.

38. Chua GP, Ng QS, Tan HK, Ong WS. Concerns and quality of life of cancer survivors across the survivorship trajectory. Int J Oncol Res. Accepted for publication.

39. Fenn KM, Evans SB, McCorkle R, DiGiovanna MP, Pusztai L, Sanft T, et al. Impact of financial burden of cancer on survivors' quality of life. J Oncol Pract. 2014;10:332-8.

40. Altice CK, Banegas MP, Tucker-Seeley RD, Yabroff KR. Financial hardships experienced by cancer survivors: a systematic review. J Natl Cancer Inst. 2017;109(2):djw205.

41. Barbaret C, Brosse C, Rhondali W, Ruer M, Monsarrat L, Michaud P, et al. Financial distress in patients with advanced cancer. PLoS One. 2017;12(5): e0176470.

42. Syed ST, Gerber BS, Sharp LK. Traveling towards disease: transportation barriers to health care access. J Community Health. 2013;38(5):976-93.

43. Ashworth RE, Wu JJ, Cohen RF, Novik Y. Eliminating transportation barriers to outpatient radiation therapy for underserved patients with cancer. J Clin Oncol. 2017;32(Suppl 15):e17569.

44. Ambroggi M, Biasini C, Giovane CD, Fornari F, Cavanna L. Distance as a barrier to cancer diagnosis and treatment: review of the literature. Oncologist. 2015;20:1378-85.

45. Institute of Medicine. Engaging patients, families and communities. In: Smith M, Saunders R, Stuckhardt L, et al., editors. Best Care at Lower Cost: The Path to Continuously Learning Health Care in America. Washington, DC: National Academies Press; 2013. p. 189-217.

46. Gu X, Chen M, Liu M, Zhang Z, Cheng W. End-of-life decision-making of terminally ill cancer patients in a tertiary cancer center in Shanghai, China. Support Care Cancer. 2016;24:2209-15.

47. Doubova SV, Aguirre-Hernandez R, Infante-Castaneda C, Martinez-Vega I, Perez-Cuevas R. Needs of caregivers of cancer patients: validation of the Mexican version of the support person unmet needs survey (SPUNS-SFM). Support Care Cancer. 2015;23(10):2925-35.

48. van Ryn M, Sanders S, Kahn K, van Houtven C, Griffin JM, Martin M, et al Objective burden, resources, and other stressors among informal cancer caregivers: a hidden quality issue? Psycho-Oncology. 2011;20(1):44-52.

49. Chow WH, Chang P, Lee SC, Wong A, Shen HM, Verkooijen HM. Complementary and alternative medicine among Singapore cancer patients. Ann Acad Med Singap. 2010;39:129-35.

50. Richardson MA, Sanders T, Palmer JL, Greisinger A, Singletary SE. Complementary/ alternative medicine use in a comprehensive cancer center and the implications for oncology. J Clin Oncol. 2000;18(13):2505-14.

51. Watkins CL, Fernandez-Robles C, Miller KM, Pine A, Stern TA. Use of complementary and alternative medicine by patients with cancer. Prim Care Companion CNS Discord. 2011;13(2):PCC.10f01011.

52. Jacobs JM, Greer J, El-Jawahri A, Nipp RD, Gallagher ER, Pirl WE, et al. The positive effects of early integrated palliative care on patient coping strategies, quality of life, and depression. J Clin Oncol. 2017:35(Suppl 31):92

53. Zhuang $H, M a ~ Y$, Wang $L$, Zhang $H$. Effect of early palliative care on quality of life in patients with non-small-cell lung cancer. Curr Oncol. 2018;25(1): e54-8.

54. Vanbutsele G, Pardon K, Van Belle S, Surmont V, De Laat M, Colman R, et al. Effect of early and systematic integration of palliative care in patients with advanced cancer: a randomized controlled trial. Lancet Oncol. 2018;19(3): 394-404.

55. Rozman LM, Campolina AG, Lopez RVM, Kobayashi ST, Chiba T, de Soarez PC. Early palliative care and its impact on end-of-life care for cancer patients in Brazil. J Palliat Med. 2018;21(5):659-64.
56. Zambrano SC, Fliedner MC, Eychmuller S. The impact of early palliative care on the quality of care during the last days of life: what does the evidence say? Curr Opin Support Palliat Care. 2016;10(4):310-5.

57. Mawardika T, Afiyanti Y, Rahmah H. Gynecological cancer inpatients need more supportive nursing care than outpatients: a comparative study. BMC Nurs. 2019;18(Suppl 1):28.

\section{Publisher's Note}

Springer Nature remains neutral with regard to jurisdictional claims in published maps and institutional affiliations.
Ready to submit your research? Choose BMC and benefit from:

- fast, convenient online submission

- thorough peer review by experienced researchers in your field

- rapid publication on acceptance

- support for research data, including large and complex data types

- gold Open Access which fosters wider collaboration and increased citations

- maximum visibility for your research: over $100 \mathrm{M}$ website views per year

At BMC, research is always in progress.

Learn more biomedcentral.com/submissions 